\title{
Research about Chinese Military Industry Enterprises' Operation Mode of Deep Civil-Military Integration
}

\author{
Liang Jiang \\ Harbin Institute of Technology, Harbin, Heilongjiang Province, China
}

\begin{abstract}
Development with deep civil-military Integration is the common choice of many countries around the world currently. In order to explore the path of development with deep civil-military Integration of Chinese military industry enterprises, this paper analyzes characteristics of current operation mode of military industry enterprises and issues existed in operation mode of military industry enterprises under the situation of deep civil-military Integration development from the perspective of operation mode. And this paper also comes up with the idea of innovating operation modes of enterprises from the aspects of financing, technology, marketing and talents team building, etc. expecting to bring about inspiration to practice to adapt to the trend of deep civil-military integration development.
\end{abstract}

Index Terms - Civil-Military Integration, Operation Mode, Military Industry Enterprise

\section{Introduction}

Chinese military industry enterprises have become the main force of producing national defense weaponry and equipment with development for several decades. In the face of urgent demand for strengthening national defense and army, the country raised the strategic layout of deep civil-military integration, expecting to promote development of civil-military integration by policy guidance from national level and make more private enterprises entering weaponry and equipment market. For example, whole army weaponry and equipment purchasing information website is the authorized platform for publishing information of purchasing demand for weaponry and equipment of whole army. Besides, it is an important path to participate in competition of army equipment market as well as to get army's demand information. Private enterprises entering the market will certainly promote competition, which is beneficial to improving weaponry and equipment level comprehensively. In the meantime, this will affect the military industry enterprises' vested interest of monopoly. Under the circumstance with diversified market competition, military industry enterprises' traditional management system, operation mode that has formed for many years are no longer suitable for current demand of development. In order to maintain the constant momentum of development in fierce competition, military industry enterprises have to reform the management system and modify operation mode by emancipating the mind and coordinating the resources to realize civil-military integration development. This paper researches the military industry enterprises' operation mode of civil-military integration.

\section{Characteristics of Chinese Military Industry Enterprises' Operation Mode}

Military industry enterprises shoulder the important responsibility of developing national defense industry and have formed a relatively fixed operation mode for many years. This mode consists of military departments making request to military industry enterprises in related field, providing them with capital guarantee, and military industry enterprises realizing the development and production of products as the main body. There are 10 main military industry groups with characteristics of operation development as follows:

1) Operation of capital is relatively monotonous. The main source of capital is the military's order, national financial allocation and policy-based lending. Some enterprises make corporatization reform and bring in social capital by going public, issuing bonds or funds. However, proportion of capital from these sources is still relatively low.

2) Military industry enterprises gain the marketing channels mainly by tracking the military's demand, supplemented by tracking civilian market. And they have a deeper understanding of equipment demands from the military, while are lack of knowledge of application and requirements for civilian market. And their main income is from military products, supplemented with income from civilian market. And proportion of income from military products is bigger.

3) Operation mode of technology and production of military industry enterprises is relatively fixed. Their development and production are based on demand of the military according to the relevant procedures of the military's development and production. There are strict rules and procedures in every stage of the procedure including fundamental research, pre-research, project demonstration, verification, engineering development, mass production, repair and service. Moreover, research and production are mainly outsourced to internal companies in the group, because they tend to outsource the task of development and production to internal companies in the group rather than external private companies for models for which they are responsible.

4) Human resources management mainly conforms to the traditional state-owned enterprises' human resources management rules. Through development of personnel usages for years, technological, managing and capital operational talents teams have gradually formed inside the group and rarely bring in social personnel into the system in enterprise operation. 


\section{Issues in Operation Mode of Deep Civil-Military Integration Development for Military Industry Enterprises}

\section{A. Development Status of Deep Civil-Military Integration of Military Industry Enterprises}

Military industry enterprises began conducting civilmilitary integration since 1980s and generally built a marketdriven operation system with significant achievements. Newlydeveloped products exhibit characteristics of diversification, serialization and high quality [1]. And some of the products have reached the advanced level among the products of the same category around the world. According to the research about civil-military integration in all the fields and related results collected from domestic institutes, the degree of civilmilitary integration of China is around 30\%, indicating that we are advancing from initial stage to the mid stage and from preliminary integration to deep integration [2].

Although we have made achievements, we must notice the problems we have to face. First, military technologies and civil technologies are still developed separately. For the military industry still covers more than $50 \%$ across the military industry enterprises with their core enterprise competence focused on military products. Second, applications of military-to-civil transfer techniques don't form an industrialized development scale. For instance, civil planes don't form a scale of usage, civil nuclear power develops slowly, civil aerospace still cannot compete with foreign country and civil marine still has great discrepancies in the field of high technology ships, ocean engineering [3] and etc. Third, civil technologies have not been transplanted into development of military products sufficiently. For example, high-end technologies included in civil technologies such as modern information technologies, electronic technology, software and etc. have not been deeply applied to military field, which affects the progress of military products' development and causes waste of resources.

\section{B. Issues in Operation Mode of Deep Civil-Military} Integration for Military Industry Enterprises

Operation mode is a key factor that affects enterprises' civil-military integration development. There are some main issues as follows due to the influence of traditional planned economy system and national defense industry profit layout.

1) First, the related policy has shortcomings in expanding financing channels and capital operation in face of immense social fund of China. Second, there are less modes and methods to operate. For example, stock market is the main financing channel. And military industry enterprises rarely bring in venture capital.

2) Military industry enterprises emphasize military products market development. However, they usually passively wait for customers from civil market. And they miss chances to apply advanced military technologies to products and form a big scale of application due to absence of knowledge of civil demand.

3) Since military industry enterprises take development and production of military products as their primary tasks, they have shortcomings in extending from military technologies to civil products and from military products to civil application. According to statistics, $80 \%$ of technologies can be shared by both military and civil application [4]. But engineers have an insufficient knowledge of civil demand at the beginning of product design, which makes for problems such as high cost, low convenience, incomplete technological index coverage and excess of civil demand when military products are applied to civil use.

4) Military industry enterprises seldom bring in social force of development in producing new military equipment, technologies and products. And they constantly pursue large and comprehensive development and production system, which leads to the situation that military products and civil products cannot integrate in personnel, technology, production and etc.

5) In development of talents team, military industry enterprises constantly produce talents from their own system no matter they are managing talents or technological talents. But private enterprises bring in the mode of talents introduction, which is rarely applied in military industry enterprises. And Introduction of technological talents is limited by the insufficiency of reward and encourages policies.

\section{Suggestions}

\section{A. Constructing Diversified Financing Mode is the Key}

Currently, military industry enterprises has long been depending on bank loans and issuing short-term corporate bonds as their main financing methods. High financing cost and monotonous channel make deep integration of capital and technology very difficult. And this causes a low conversion efficiency of military industry research outcomes. In order to promote deep civil-military integration development, military industry enterprises should fully take advantage of capital market and actively explore docking of financing mode such as $\mathrm{VC}$ and PE to high technology with different financing methods based on life-cycle characteristics of equipment. And they should also make full use of the important effect of capital factors in transition of deep civil-military integration development of military industry enterprises. By applying diversified financing modes can military industry enterprises improve the perfect integration of capital and technology.

\section{B. Building Technological Innovation of Civil-Military Integration Is Basis}

Under the circumstance with national policy of intensifying equipment purchasing system reform, many private enterprises participate in the competition of military products, which bring up impact to military industry enterprises' territory. In order to make breakthroughs in development of civil-military integration and maximize the profit, military industry enterprises should actively bring in advanced techniques from private enterprises and colleges and integrate them into civil-military development processes with outcomes of products by adopting innovation modes such as original innovation, integration innovation and collaboration innovation. Meanwhile, military industry enterprises should allocate resources and energy to the both ends of value chain 
smile curve of high-end equipment manufacturing, focusing on high-end fields with high technical content and high economic value added.

\section{Breaking Single Marketing Mode is Guarantee}

Task of military industry enterprises mainly comes from national plan. And their customers are the armies. So their market channel is single and marketing method is inadequate. In the trend of military-to-civil transfer and private enterprises participating in the military products market, military industry enterprises' market is not limited to their original planned tasks. Civil-military integration is run according to the law of market economy, so it can be generally put into the background of market economy except for those projects classified. What military industry enterprises require is to break the original marketing thinking and build a complete sales management system. In this way, they can intensify the innovation research in civil market with the application in the military field consolidated. Military industry enterprises should transfer from the original mode of users' demand driving development of enterprises to the mode based on user experience and market, building an innovative sales mode of understanding and guiding users' demand. Moreover, military industry enterprises should transform from products mode to service mode, offering customized services that meet customers' requirements. And military industry enterprises should offer open architecture and encourage secondary innovation. Besides, they should transit from caring the number of customers to the number of users.

\section{Building a Market-Driven Talents Team is Essential}

Talents are the essential of deep civil-military integration development of military industry enterprises. As a consequence, configuring the outstanding talents team with effective incentive rules is the basic guarantee of realizing the vision of enterprises. Currently, government actively encourages colleges and research institutes' technical personnel to build enterprises holding stocks and apply development mode of mixed ownership. So military industry enterprises should grab the opportunity to build a performance-based incentive rule of modern enterprises, allowing equity participation with technical and managing factors. By doing this, individual development and benefit can be bound with development of enterprises, which accelerates the development of civil-military integration strategy and outcomes of military industry technology. Meanwhile, under the constraint of State Secrets Law, military industry enterprises should bring in all kinds of talents in any fields rather than bring in outstanding talents inside the group. And building a group of talents and specialists for each company will facilitate the transfer of technological outcomes and industry optimization.

\section{Conclusions}

Military industry enterprises have many things to do on the road of development of civil-military integration. Operation mode of enterprises determines if they can withstand the trial under the big environment of reform and enjoy stable growth. The manager of an enterprise should innovate from the aspects of financing mode, technological innovation, marketing, personnel training and etc. And the manager should actively transform to adapt to trend of development of civil-military integration, and take advantage in development by occupying the high ground of market.

\section{References}

[1] Yan Chen, "Discussion about Realizing Path of Civil-Military Integration Development of Military Industry Enterprises," Chinese military-to-civil transfer, no.11, pp. 44-48, 2010.

[2] Jinging Bi, Tianyou Ren, "Report about Chinese Civil-Military Integration Development 2014," National Defense University Press, 2014, pp. 2-3.

[3] Zhirong Luo, Chinese Exploration of Civil-Military Integration, Civilization of Enterprises, no.3, pp. 13-20, 2014.

[4] Yanqiu Mei, Weichao Zhang and Chunli Peng, "Transition of National Defense Technical industry and Civil-Military Integration Development," Journal of Air Defense Soldier Students, vol.81, no. 1, pp. 75-76, February 2014. 